superjacent patches of Boulder-clay to be in place? Unless he refuses credence to the observations of Messrs. Prestwich, H. B. Woodward, and C. Reid, he cannot support Sir H. Howorth.

I have confined myself to denying Sir Henry's contention that Mammoth-bearing deposits are "never underlain by Glacial Drift." I am perfectly prepared to admit that Mammoth-remains do occur under undoubted Glacial deposits, as Dr. Hicks maintains, but that is not the point in question.

A. J. Jukes-Browne.

Exeter, $F e b .7,1893$.

\title{
A BORING AT WILLOUGHBY IN LINCOLNSHIRE.
}

Sir,--I think you will find that the boring at Willoughby, mentioned in the paragraph quoted from the "Morning Post" in the Geological Magazine for February, was made in 1887. I have some particulars of the strata passed through which I bope to publish shortly, and will only now say that it supplies valuable information about the subterranean structure of that part of Lincolnshire. The boring passed directly from Glacial Drift into the so-called Neocomian, without the intervention of any kind of Chalk. Water was found at the top of the Spilsby Sandstone.

ExeTER, $F t b .7$.

A. J. JuKes-Browne.

\section{SUBTERRANEAN EROSION.}

Sir,-In the Grologioal Magazing for September, 1892, Mr. Morton, F.G.S., criticised a paper I read in December, 1891, before the Geological Society, entitled "The Subterranean Erosion of the Glacial Drift, a probable cause of Submerged Peat and Forest Beds" (Quart. Journ. Feb. 1892, pp. 96-103). So far as Mr. Morton's criticisms partake of the nature of a defence of his theory of the origin of the submerged Peat and Forest-beds of Lancashire and Cheshire as described in his work entitled "The Geology, of the Country around Liverpool" I do not propose to discuss, for if $\mathrm{Mr}$. Morton's theory be right then my theory must be wrong, and vice versa.

Mr. Morton's remarks, however, go beyond the mere local application of the principle of subterranean erosion. In concluding, he writes, "It is very remarkable that such an active agent has not been observed in Tertiary formations of the South of England where the beds of clay and sand are similar and occur under the same conditions." I go further even than Mr. Morton, viz.-If the principle of Subterranean Erosion be true at all it will prove as true in the past as in the present (under the conditions mentioned) and as wide in its operations as the law of gravitation. In the Quart. Journ. of the Geol. Soc. vol. xlviii. p. 103, I defined Subterranean Erosion as follows :-

"That wherever water percolated through such unconsolidated beds as clays, sands, and gravels, along an inclined plane, it was constantly carrying the lighter materials of such strata towards the nearest point of escape. The nearer the approach to the point of escape, 
the greater became the power of subterranean erosion. This action caused lateral subsidence."

I maintain (inter alia) this "principle of geology" may be responsible for such widely separated events as the Submerged Peat and Forest-beds of the Estuary of the Thames, the swamps of America, the Contorted Drifts of Norfolk, and the "thick coals" of South Staffordshire.

Wilitam Shone.

Upton PakK, Chester, Dec. 18, 1892.

\section{OBITUARY.}

PROFESSOR JOHN O. WESTWOOD, M.A., F.L.S., \&C.

Hon. President Entomonogical Society of London; Hope Professor of Zoology iN the University of Oxford.

BorN 1805. Died 2 JANUART, 1893.

Another venerable Professor has passed away in the opening of the New Year. John Obadiah Westwood was the son of the late Mr. Westwood, of Sheffield, and was born in that town in the year 1805. Having been privately educated at Lichfield, he shortly after commenced active life and migrated to London, where be early displayed an ardent love of Entomology. He was one of the original members of the Entomological Society of London, founded in 1834, and after being twice President, was elected honorary life President. His "Introduction to the Modern Classification of Insects" and the "Entomologist's Text-Book" appeared in 1838; his "British Butterflies and their Transformations," in 1841 ; "Arcana Entomologica"; "British Moths and their Transformations," \&c. in 1845; "Cabinet of Oriental Entomology," in 1848; Descriptions of Fussil Insects in the Rev. P. B. Brodie's " History of the Fossil Insects in the Secondary Rocks of England" (London 1845 with 11 plates), and a valuable paper on Purbeck Insects (Quart. Journ. Geol. Soo., Vol. ix. pp. $378-396,1854)$.

In 1855 the Royal Society presented him with one of the Royal Medals in recognition of his valuable contributions to Entomology.

In $1861 \mathrm{Mr}$. Westwood was appointed to the professorship of Zoology in the University of Oxford, then newly founded by the munificence of the late Rev. F. W. Hope. Soon afterwards the Professor was made an Honorary Fellow of Magdalen College, Oxford. Professor Westwood was joint author with Mr. C. SpenceBate, of a "History of the British Sessile-eyed Crustacea" (2 vols., 1863-1868). He was a Fellow of the Linnzean Society for nearly 70 years, and was an Honorary or Corresponding Member of the Entomological and Zoological Societies of Paris, Holland, Belgium, Berlin, Stettin, Munich, Vienna, Stockholm, St. Petersburg, Moscow, Quebec, Boston (U.S.A.), and many other Societies. His separate papers are too numerous to quote here. As a draughtsman of Insects he was highly skilled. $\mathrm{He}$ continued his lectures at Oxford till a very recent date, and his loss is deeply regretted in the University. 